"Relevance of corporate environmental reports produced by listed South African companies"

\section{AUTHORS}

ARTICLE INFO

DOI

RELEASED ON

JOURNAL

FOUNDER

\section{Peter Nasiema Kamala}

Peter Nasiema Kamala (2016). Relevance of corporate environmental reports produced by listed South African companies. Environmental Economics, 7(1), 97107. doi:10.21511/ee.07(1).2016.12

http://dx.doi.org/10.21511/ee.07(1).2016.12

Thursday, 24 March 2016

"Environmental Economics"

LLC "Consulting Publishing Company "Business Perspectives"

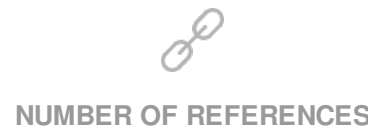

0

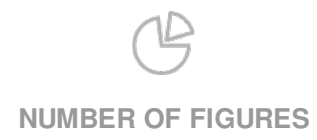

0

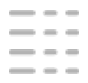

NUMBER OF TABLES

0

(C) The author(s) 2022. This publication is an open access article. 
Peter Nasiema Kamala (South Africa)

\title{
Relevance of corporate environmental reports produced by listed South African companies
}

\begin{abstract}
The broad aim of this research is to assess the relevance of environmental reports produced by the Top 100 listed South African (T100LSA) companies. The study is motivated by a lack of research on the relevance of environmental reports in South Africa, given the dramatic increase in the number of companies producing these reports as well as the expansion of the volumes of the reports produced. A content analysis of environmental reports contained in the Integrated Annual Reports (IARs), sustainability reports and companies' corporate websites is conducted using a control list.

The findings of the study reveal that in general, the environmental reports produced by the T100LSA companies are relevant as most companies have disclosed how they select stakeholders for engagement, their methods of engagement, engagement process and outcomes and how content reported on is selected. In addition, the companies have disclosed how they address and respond to key stakeholders' concerns as well as their initiatives to encourage stakeholders to participate in the companies' activities. Furthermore the companies disclose their general performance indicators. However, there is a need for improvement in the disclosure of metric to quantify the effectiveness of the stakeholder engagement and reference to GRI sector specific indicators when selecting content to report on. More importantly, there is a need to improve on the use of online features to enhance relevance of the reports such as encouraging users to be part of the writing process by enabling them to edit, analyze and share the reported information, and tracking their use of on-line reports.
\end{abstract}

Keywords: relevance, decision-usefulness, environmental reports, content analysis.

JEL Classification: Q50.

\section{Introduction}

Like any other form of accounting, the main objective of environmental reporting is to provide information that is useful to users for making decisions (FASB, 2010, p. 01; GRI, 2013, p. 17; IASB, 2010, p. 43). For environmental reports to be useful for making decisions (decision-useful), they must be both relevant and reliable (FASB, 2010, p. 19). Neither a reliable representation of an irrelevant phenomenon, nor an unreliable representation of a relevant phenomenon, helps users to make good decisions. If the reports produced are either irrelevant or unreliable, such reports do not only lead to erroneous and increasingly irreversible decisions, but also they discourage stakeholders from relying on the environmental reports produced by companies for making decisions (Kamala, 2014, p. 15).

Relevance, which is the focus of this paper refers to the capacity of reports to influence a decision by helping users to form predictions about the outcome of past, present and future events, or confirm and correct prior expectations (FASB, 2010, p. 17). For accounting information to influence a decision, it must enable users to make new predictions, confirm or correct prior predictions (FASB, 2010, p. 25). Such information must also suit the diverse expectations and decision-making needs of the intended users by addressing their concerns (GRI, 2015, p. 17). Environmental reports can only meet stakeholders'

(C) Peter Nasiema Kamala, 2016.

Peter Nasiema Kamala, Dr., Department of Management Accounting, Cape Peninsula University of Technology, South Africa. decision-making needs if the stakeholders are engaged meaningfully in the reporting process through dialogue to determine what is or is not important to them (GRI, 2015, p. 30).

Despite the recent dramatic increase in both number of companies that produce environmental reports and the volumes of the reports produced, the relevance of these reports has remained questionable for various reasons (Delmas \& Burbano, 2011, p. 64; Kim \& Lyon, 2012, p. 311; Marquis \& Toffel, 2014, p. 01). Firstly, most companies appear to have increased the quantity of their environmental reports without a meaningful stakeholder engagement exercise (Bromley \& Powell, 2012, p. 485). As a result, the stakeholders have not influenced the content presented in the reports as they have mostly been side-lined from the reporting process (Marquis \&Toffel, 2014, p. 19).

Secondly, to cater for a diverse audience of stakeholders, most companies have simply produced generic and overloaded reports that do not address the unique needs of the stakeholders (Laud \& Schepers, 2009 , p. 368). By purporting to cater for diverse stakeholder groups, many companies simply expanded their reports by dumping irrelevant information in the reports. Indeed, most companies have failed to exploit their on-line capabilities to tailor environmental reports to address the unique needs of different stakeholder groups (KPMG, 2011, p. 22; Radley Yeldar \& GRI, 2011, p. 02). Instead, they have typically provided over-aggregated environmental information without localizing the content or providing supporting detail, in order to cater for an ever growing number of stakeholder groups (Business 
\& Society, Morris \& Chapman, 2010, p. 14; Laud \& Schepers, 2009, p. 368).

Likewise, most companies have not leveraged their on-line capabilities to produce more timely reports. Instead they have increasingly aligned their environmental reporting cycle to their annual reports, thus have failed to take advantage of their on-line capabilities to report more frequently before their environmental information loses its relevance (FSC, Sustainability \& KPMG, 2010, p. 03; Radley Yeldar \& GRI, 2011, p. 02). Thirdly, some companies have deliberately embarked on providing dis-informative environmental reports with more scenic landscape photographs (green glossies) than the actual relevant information required by stakeholders (Delmas \& Burbano, 2011, p. 64).

Given that environmental reporting is aimed at providing relevant information that is useful to a wide range of users for making decisions (GRI, 2013, p. 17), the concerns raised above cast serious doubts on the ability of the current environmental reports to inform decisions. Consequently, debate is rife as to whether the environmental information provided by companies is relevant to users and whether the users perceive reports produced to be relevant for their decision-making decisions (European Commission, 2011, p. 92; p. 93; Hwang, Khoo \& Wong, 2013, p. 178; Said, Ahmad \& Senik, 2013, p. 440).

In the South African context, the question of whether environmental reports produced by companies are relevant was last examined more than five years ago (De Villiers \& Van Staden, 2010). This research aims to fill this gap in the literature by evaluating the content of the environmental reports produced by the T100LSA companies. Accordingly, the main objective of this study is to evaluate the relevance of corporate environmental reports produced by T100LSA companies.

The rest of the article proceeds as follows: Section 1 reviews the relevant prior literature. It provides the theoretical perspective adopted in this article. Section 2 presents the methodology, followed by results and discussion in Section 3. Final section 6 provides the summary and conclusion of the article.

\section{Literature review}

In many countries, most researchers have argued that companies do not provide relevant environmental information to aid users in making decisions, but rather as a means to legitimize their operations in society and subsequently reap the rewards of such legitimacy (De Villiers \& Van Staden, 2009; De Villiers \& Van Staden, 2006, p. 763; De Villiers \& Lubbe, 2001, p. 81; Deegan, 2002, p. 302; Jollands, Akroyd \& Sawabe, 2012, p. 6; O'Donovan, 2002, p. 346). This argument is supported by the finding that most companies seem to provide environmental information without enquiring what the users require (De Villiers \& Van Staden, 2008, p. 1). In addition, firms experiencing an environmental crisis often disclose more general and unimportant environmental information (green-wash) to create the impression of being environmentally sensitive (Delmas \& Burbano, 2011, p. 64; De Villiers \& Van Staden, 2009 , p. 31). Other researchers have maintained that under the voluntary environmental reporting regimes, environmental information disclosed is inadequate even when relevant (Antonites \& De Villiers, 2003, p. 10; Danastas \& Gadenne, 2005, p. 85; Laud \& Schepers, 2009, p. 366; Solomon \& Solomon, 2006, p. 573).

Similarly, some researchers have found environmental information to be simply irrelevant and unreliable (Campbell \& Slack, 2008, p. 5; Delmas \& Burbano, 2011, p. 64). In addition, some have lamented that users distrust or are sceptical of environmental information (IRC, 2011, p. 01). Likewise, some companies have decried a lack of request for their environmental information or feedback where such information is published, which indicates a lack of demand for environmental information, particularly when such information is deemed to be irrelevant (European Commission, 2011, p. 91).

On the contrary, some researchers have contended that users do use environmental information as evidenced by stock market reaction to disclosure of environmental performance information (Came, 2011, p. 01; Flammer, 2012, p. 01; Moneva \& Cuellar, 2009, p. 441). Similarly, some researchers have opined that users do not only use environmental information, but also they influence the environmental reporting practices to suit their needs (Islam \& Deegan, 2010, p. 13; Deegan \& Islam, 2009, p. 1; Deegan, 2002, p. 282; Deegan \& Blomquist, 2006, p. 370).

Other researchers have documented mixed findings whereby users perceive environmental information to be relevant, and yet they rank it below financial information (Deegan \& Rankin, 1997, p. 580; Myburgh, 2001, p. 211; Stainbank \& Peebles, 2006, p. 75). Conversely, some researchers have found that users rank environmental information higher than certain types of information such as social information and employee information (Epstein \& Freedman, 1994, p. 106; Stainbank \& Peebles, 2006, p. 75).

Various researchers have investigated the relevance of environmental reports to specific user groups, most notably the investment analysts, who are perceived to be sophisticated, most informed and articulate user group of company reports (Bartlett \& Chandler, 1997, p. 254; Beattie \& Pratt, 2002, p. 01; 
Campbell \& Slack, 2008, p. 05; Johansson, 2007, p. 30; Deegan \& Rankin, 1999, p. 326; Rowbottom \& Lymer, 2007, p. 1). The researchers have found that analysts do not perceive environmental reports to be relevant, as only financial statements are relevant to this user group. Other researchers have argued that environmental information is relevant to some user groups and not to others (European Commission, 2011, p. 91). Deegan and Rankin (1997, p. 580) for example found that environmental information was of importance to non-institutional investors but of little importance to investment analysts. Likewise the European Commission (2011, p. 91) found that environmental reports were relevant to the civil society, media and consumers but not to investors, analysts and employees.

Some researchers have lamented that users were asking for better environmental information than they were receiving (Haque et al., 2013, p. 21; Danastas \& Gadenne, 2005, p. 85). Haque et al. (2013, p. 21) found an expectation gap between the climate-change related corporate governance information reported by companies and the information sought by stakeholders. Similarly, Danastas and Gadenne (2005, p. 85) found that nongovernmental organizations (NGOs) in Australia used corporate environmental reports, however, they perceived the reports to be insufficient even when relevant. The researchers speculated that the provision of inadequate environmental information may indicate a lack of commitment to accountability and transparency.

Consistent with the international trends, studies conducted on environmental reporting in South Africa have revealed a growing interest in corporate environmental reports among users (De Villiers \& Vorster, 1995, p. 57; De Villiers, 1998a, p. 159; De Vries \& De Villiers, 1997, p. 3; De Villiers \& Van Staden, 2010b, p. 442; Mitchell \& Quin's, 2005, p. 26). More specifically, the studies have indicated that users want more relevant environmental information than was being provided. The studies have further found that environmental reports provided were perceived to be irrelevant, insufficient, unsystematic and incomparable among the reporting companies. Similarly, Mitchell and Quinn (2005, p. 17), and Myburgh (2001, p. 211), have found that there is an expectation gap between users and preparers on the environmental information that should be disclosed by South African companies.

Unlike in the developed countries, there is a paucity of research which investigates the decisionusefulness, and particularly the relevance of environmental reports in South Africa. Moreover, the research conducted on relevance of environmental reports is outdated in the contemporary dynamic reporting arena and therefore there is a need for more recent research (De Villiers \& Van Staden, 2010b, p. 442; De Villiers \& Vorster, 1995, p. 57; De Villiers, 1998a, p. 159; De Vries \& De Villiers, 1997, p. 03; Mitchell \& Quinn, 2005, p. 17). This study aims to fill in the gap in the literature by investigating the relevance of environmental reports produced by the T100LSA companies.

\section{Methodology}

Content analysis methodology was employed to evaluate the relevance of corporate environmental reports produced by the T100LSA companies. This methodology was systematically used to identify presence of specified characteristics of messages related to relevance of the environmental reports located in IARs, websites and corporate sustainability reports, regardless of whether the messages were in form of text, audio, video, graphical or pictorial. This method was preferred because it is an unobtrusive technique, that avoids problems of non-response bias, and that enables a researcher to collect data in a variety of forms (Zadjali, 2011, p. 01).

2.1. Design of the research instrument. Companies can only produce relevant reports if stakeholders are meaningfully engaged in the reporting process through a dialogue meant to understand their information needs (GRI, 2015, p. 30). Accordingly, the disclosure of stakeholder engagement practices can and was used as a proxy to gauge the relevance of the environmental reports. To evaluate the relevance of the environmental reports, a checklist was designed from the Global Reporting Intitiaves' guidelines which are the de facto standards for environmental reporting (Fonseca, 2010, p. 05). The checklist contained key items whose disclosure in an environmental report would indicate its relevance. These include the disclosure of the identification, selection and prioritisation of stakeholders to be engaged, use of a variety of methods to engage them, determination of what is of concern to stakeholders, selection and reporting content that addresses these concerns (GRI, 2015, p. 29). In addition, the disclosure of the engagement process and outcomes, disclosure of stakeholder' participation in the reporting process, nature of information disclosed and the use of on-line features to enhance the relevance of the reports to the intended users (GRI, 2015, p. 30).

2.2. Data collection. The data collection exercise entailed scanning of IARs, corporate sustainability reports and websites of companies to determine the presence of pre-listed items, related to relevance of environmental reports, which were contained in a control list. The total number of companies whose environmental reports contained a pre-listed item 
was computed and expressed as a percentage of the total number of sampled companies. These were then summarized in tables under a column titled "companies that disclose". Likewise the total number of companies whose environmental reports did not contain a pre-listed item was computed and expressed as a percentage of the total number of sampled companies. These were then summarized in tables under a column titled "companies that do not disclose" (See Table 1, 2, 3, 4, and 5).

2.3. Population and sample selection. The population of the proposed research comprized the top 100 operating companies on the Johannesburg Securities Exchange (JSE). The sample consisted of 66 top 100 JSE listed operating companies based on market capitalisation as quoted on the Sharenet website - a reliable website that provides on-line information on companies listed on the JSE - on 1st January 2015. The 44 companies excluded from the sample were either investment companies which do not undertake operational activities or subsidiaries of holding companies already included in the sample, or simply listed securities given that they are not physical companies.

The top 100 JSE listed operating companies were selected because of their significant environmental impact in the areas in which they operate, given their large sizes and presence in many provinces of South Africa (Jose \& Lee, 2006, p. 311). In addition, their
IARs, sustainability reports and company websites were more readily available than those of other forms of businesses. Furthermore, these companies are well resourced and can thus afford to employ dedicated personnel to focus on environmental issues, as well as afford to prepare environmental reports on a variety of media.

\section{Results and discussions}

3.1. Disclosure of selection of stakeholders for engagement and methods used to engage them. Environmental reports can be only relevant if they reflect the needs of the stakeholders (Noked, 2013, p. 01). This requires that the stakeholders be meaningfully engaged by using systematic techniques to identify and prioritize the target audience and their respective information needs and expectations. Since the effectiveness of different methods of engaging with the stakeholders varies from one stakeholder group to another, a company must employ different methods when engaging different stakeholders (GRI, 2015, p. 30). In short, the extent of disclosure of the selection of stakeholders for engagement and the methods employed to engage them can be partly used to gauge the relevance of the environmental reports.

As shown in Table 2, the results of current study show that $100 \%$ of sampled companies identified stakeholders for engagement purposes, while $98 \%$ of companies provided an indication of the stakeholder's relative importance.

Table 1. Disclosure of selection of stakeholders for engagement and the methods employed to engage the stakeholders

\begin{tabular}{|c|c|c|c|c|c|}
\hline No & Category & Disclosure item & $\begin{array}{c}\text { Percentage of } \\
\text { companies that } \\
\text { disclose }\end{array}$ & $\begin{array}{c}\text { Percentage of } \\
\text { companies that do } \\
\text { not disclose }\end{array}$ & Total \\
\hline \multirow{2}{*}{1} & \multirow{2}{*}{$\begin{array}{l}\text { Selection of } \\
\text { stakeholders for } \\
\text { engagement }\end{array}$} & Identification of stakeholders for engagement purposes & $100 \%$ & $0 \%$ & $100 \%$ \\
\hline & & Indication of stakeholders' relative importance & $98 \%$ & $2 \%$ & $100 \%$ \\
\hline \multirow{2}{*}{2} & \multirow{2}{*}{$\begin{array}{l}\text { Methods of } \\
\text { stakeholder } \\
\text { engagement }\end{array}$} & Methods employed to engage stakeholders & $100 \%$ & $0 \%$ & $100 \%$ \\
\hline & & Use of different methods to engage different stakeholders & $98 \%$ & $2 \%$ & $100 \%$ \\
\hline
\end{tabular}

Source: Global Reporting Initiative (2015), Kamala (2014).

In as far as the methods of engagement of stakeholders are concerned, Table 2 indicates that $100 \%$ of sampled companies disclosed the methods employed to engage stakeholders, while $98 \%$ of sampled companies disclosed that they used different methods to engage different stakeholders.

3.2. Disclosure of engagement process, outcomes and criteria for selecting the content reported on. The disclosure of engagement process, outcomes and criteria for selecting content to be reported on is important because only by disclosing these items a company can truly demonstrate how the stakeholder concerns are incorporated in the content reported (GRI, 2011, p. 10). Therefore, the extent of disclosure of the engagement process, outcomes and criteria for selecting content to be reported on can partly be used to gauge the relevance of environmental reports.

With regard to the disclosure of engagement process, outcomes and criteria for selecting content to be reported, the results of current study reveal that $89 \%$ of top 100 sampled companies disclosed their process of engagement with stakeholders (See Table 3). By contrast, only $39 \%$ of sampled companies used a consistent metric to quantify the effectiveness of their stakeholder engagement. $79 \%$ of sampled companies, disclosed that stakeholder engagement was specifically undertaken as a part of the reporting process, while $77 \%$ of them disclosed the key topics, outcomes and concerns raised through the stakeholder engagement. 
Table 2. Disclosure of the engagement process, outcomes and criteria for selecting content to be reported on

\begin{tabular}{|c|c|c|c|c|c|}
\hline No & Category & Disclosure item & $\begin{array}{c}\text { Percentage of } \\
\text { Companies that } \\
\text { disclose }\end{array}$ & $\begin{array}{l}\text { Percentage of } \\
\text { companies that } \\
\text { do not disclose }\end{array}$ & Total \\
\hline \multirow{4}{*}{3} & \multirow{4}{*}{$\begin{array}{l}\text { Stakeholder } \\
\text { engagement } \\
\text { process and } \\
\text { outcome }\end{array}$} & Process of engagement with stakeholders & $89 \%$ & $11 \%$ & $100 \%$ \\
\hline & & $\begin{array}{l}\text { Use of a consistent metric to quantify the effectiveness of the } \\
\text { stakeholder engagement }\end{array}$ & $39 \%$ & $61 \%$ & $100 \%$ \\
\hline & & $\begin{array}{l}\text { Stakeholder engagement specifically undertaken for as a part } \\
\text { of reporting process }\end{array}$ & $79 \%$ & $21 \%$ & $100 \%$ \\
\hline & & $\begin{array}{l}\text { Key topics, outcomes and concerns raised through } \\
\text { engagement }\end{array}$ & $77 \%$ & $23 \%$ & $100 \%$ \\
\hline \multirow{8}{*}{4} & \multirow{8}{*}{$\begin{array}{l}\text { Selection of } \\
\text { content }\end{array}$} & Criteria for selection of reported content & $98 \%$ & $2 \%$ & $100 \%$ \\
\hline & & Rationale behind the choice of key impacts & $86 \%$ & $14 \%$ & $100 \%$ \\
\hline & & Explanation of how the issues are prioritized within reports & $91 \%$ & $9 \%$ & $100 \%$ \\
\hline & & $\begin{array}{l}\text { Consultation with stakeholders when selecting the content to } \\
\text { report on }\end{array}$ & $77 \%$ & $23 \%$ & $100 \%$ \\
\hline & & $\begin{array}{l}\text { Reference to the GRI guidelines when selecting the content to } \\
\text { report on }\end{array}$ & $86 \%$ & $14 \%$ & $100 \%$ \\
\hline & & Reference to GRI sector specific indicators & $41 \%$ & $59 \%$ & $100 \%$ \\
\hline & & Process of assessing materiality of issues & $71 \%$ & $29 \%$ & $100 \%$ \\
\hline & & Materiality matrix & $70 \%$ & $30 \%$ & $100 \%$ \\
\hline
\end{tabular}

Source: Global Reporting Initiative (2015), Kamala (2014).

With regard to the disclosure of criteria for the selection of environmental content reported on, $98 \%$ of sampled companies in the current study disclosed this item, whereas $86 \%$ of companies disclosed the rationale behind their choice of key impacts. Among the sampled companies, $91 \%$ of them provided an explanation of how issues were prioritized within their reports, while $77 \%$ indicated that stakeholders were consulted when selecting the content to report on. Of the sampled companies, $86 \%$ referred to the GRI guidelines when selecting the content to report on, however only $41 \%$ referred to GRI sector specific indicators. $71 \%$ of sampled companies disclosed that they had a process of assessing materiality of issues, while $70 \%$ of them disclosed their materiality matrix used for linking the stakeholder groups to the topics selected for reporting.

The above results are consistent with those of KPMG (2008, p. 40) which indicated that nearly $60 \%$ of sampled companies disclosed that they selected reporting content according to their own objectives, whereas $77 \%$ of the Fortune 250 companies disclosed that they relied on the GRI guidelines to select the content to report on.

3.3. Disclosure of how companies address stakeholders' concerns and encourage stakeholder participation. For a company's environmental report to provide relevant information, it must address the key stakeholders concerns (Noked, 2013, p. 01). The more a company encourages stakeholder participation in its activities, the more it is likely to obtain stakeholder feedback required to provide relevant information (CERES \& ACCA, 2010, p. 13). Therefore an analysis of how a company addresses stakeholders' concerns and encourage stakeholders' participation in its activities can partly be used to gauge the relevance of the environmental information.

As evident in Table 4 below, the results of the current study show that $83 \%$ of the top 100 sampled companies disclosed how they addressed key stakeholders' concerns. Of the sampled companies, $77 \%$ characterized and described stakeholders' interest and needs for environmental information. A similar percentage described the efforts made to cater for specific needs of different stakeholders. As far as how the issues which are disclosed are determined, $70 \%$ of the companies disclosed the specific concerns raised during the stakeholder engagement process. Only 55\% of the companies disclosed any stakeholders' criticisms or even responded to the criticisms. Worse still, only $41 \%$ of the companies disclosed that they had used GRI sector specific indicators when determining what to report on.

Table 3. Disclosure of how companies address stakeholders' concerns and encourage stakeholder participation

\begin{tabular}{|c|c|c|c|c|c|}
\hline No & Category & Disclosure item & $\begin{array}{l}\text { Percentage of } \\
\text { companies that } \\
\text { disclose }\end{array}$ & $\begin{array}{l}\text { Percentage of } \\
\text { companies that do } \\
\text { not disclose }\end{array}$ & Total \\
\hline \multirow[b]{2}{*}{5} & \multirow{2}{*}{$\begin{array}{l}\text { Key stakeholders' } \\
\text { concerns }\end{array}$} & How key stakeholders' concerns are addressed & $83 \%$ & $17 \%$ & $100 \%$ \\
\hline & & $\begin{array}{l}\text { Characterise and describe stakeholders' interest and needs } \\
\text { for environmental information }\end{array}$ & $77 \%$ & $23 \%$ & $100 \%$ \\
\hline
\end{tabular}


Table 3 (cont.). Disclosure of how companies address stakeholders' concerns and encourage stakeholder participation

\begin{tabular}{|c|c|c|c|c|c|}
\hline No & Category & Disclosure item & $\begin{array}{l}\text { Percentage of } \\
\text { companies that } \\
\text { disclose }\end{array}$ & $\begin{array}{l}\text { Percentage of } \\
\text { companies that do } \\
\text { not disclose }\end{array}$ & Total \\
\hline & & $\begin{array}{l}\text { Efforts made to cater for specific needs of different } \\
\text { stakeholders }\end{array}$ & $77 \%$ & $23 \%$ & $100 \%$ \\
\hline \multirow{2}{*}{6} & \multirow{2}{*}{$\begin{array}{l}\text { How companies } \\
\text { respond to } \\
\text { stakeholders }\end{array}$} & $\begin{array}{l}\text { Disclosure of specific concerns raised during the stakeholder } \\
\text { engagement process }\end{array}$ & $70 \%$ & $30 \%$ & $100 \%$ \\
\hline & & $\begin{array}{l}\text { Disclosure of stakeholders' criticisms or as a response to the } \\
\text { criticisms }\end{array}$ & $55 \%$ & $45 \%$ & $100 \%$ \\
\hline \multirow{5}{*}{7} & \multirow{5}{*}{$\begin{array}{l}\text { Initiatives to } \\
\text { encourage } \\
\text { stakeholders to } \\
\text { participate in } \\
\text { companies' } \\
\text { activities }\end{array}$} & $\begin{array}{l}\text { Indication of how stakeholders are encouraged to participate } \\
\text { in companies' activities }\end{array}$ & $94 \%$ & $6 \%$ & $100 \%$ \\
\hline & & Provide an avenue for stakeholders' feedback & $92 \%$ & $8 \%$ & $100 \%$ \\
\hline & & Publicly responding to stakeholders' feedback & $73 \%$ & $27 \%$ & $100 \%$ \\
\hline & & $\begin{array}{l}\text { Provide a direct contact for the personnel responsible for } \\
\text { environmental reporting }\end{array}$ & $86 \%$ & $14 \%$ & $100 \%$ \\
\hline & & $\begin{array}{l}\text { Invited users to be part of the writing process, edit or analyse } \\
\text { information }\end{array}$ & $32 \%$ & $68 \%$ & $100 \%$ \\
\hline
\end{tabular}

Source: Global Reporting Initiative (2015), Kamala (2014).

As far as the disclosure of initiatives to encourage stakeholders to participate in companies' activities, the results reveal that $94 \%$ of companies indicated how stakeholders were encouraged to participate in companies' activities. Similarly, 92\% of companies disclosed that they provided an avenue for stakeholders' feedback, $73 \%$ of companies publicly responded to the feedback whereas $86 \%$ provided a direct contact for the personnel responsible for environmental reporting. By contrast, only $32 \%$ of the companies invited the users to be a part of the writing process by enabling the users to edit a report content, add notes or analyze information using a spread sheet.

\subsection{Disclosure of general performance indicators} and relevance enhancing on-line reporting features. The GRI has provided core indicators that are generally applicable to all businesses, and globally relevant; their methods for measurement are established and definitions are globally accepted (GRI, 2015, p. 10). Any JSE listed operating company is expected to report on these indicators (IODSA, 2012, p. 02). Provision of generally applicable historical and futuristic (targets) indicators enables users to predict the future and evaluate the past performance (PWC, 2007, p. 05). An analysis of disclosure of these indicators should reveal whether a company has provided generally relevant information, and whether that information can inform future decisions.

The advent of the internet has availed new and more effective interactive on-line features for engaging with the users of environmental reports (Radley Yeldar \& GRI, 2011, p. 05). From enabling readers to tailor reports sharing their views about reports on social networks, and enabling readers and companies alike tracking the most popular content, all which should enable a company to provide relevant information (CSR Europe, 2010, p. 15). An analysis of the content of a company website therefore should reveal how effectively it uses its website to provide relevant on-line information.

The results of current study, summarized in Table 4, show that $91 \%$ of companies reported on their generally applicable environmental indicators, while only $70 \%$ disclosed both their historical indicators and targets. With regard to the use of on-line features to enhance the relevance of the reports, the results indicate that $85 \%$ of sampled companies used some on-line features for this purpose, whereas $79 \%$ of companies' websites allowed users to tailor their reports according to their needs. By contrast, only $32 \%$ of companies used externally recordable web features to enable readers to edit and share their views about a company report.

Similarly, only $32 \%$ of companies used web technologies such as the social media to engage with the stakeholders. Even more dissappointing, only $2 \%$ of companies used on-line facilities such as hit counters to track the number of stakeholders that accessed their on-line environmental reports.

Table 4. Disclosure of general performance indicators and relevance enhancing on-line reporting features

\begin{tabular}{|c|l|l|c|c|c|}
\hline No & \multicolumn{1}{|c|}{ Category } & Disclosure item & $\begin{array}{c}\text { Percentage of } \\
\text { companies that } \\
\text { disclose }\end{array}$ & $\begin{array}{c}\text { Percentage of } \\
\text { companies that do } \\
\text { not disclose }\end{array}$ & Total \\
\hline \multirow{2}{*}{8} & $\begin{array}{l}\text { General } \\
\text { performance } \\
\text { indicators }\end{array}$ & Generally applicable environmental indicators & $91 \%$ & $9 \%$ & $100 \%$ \\
\cline { 2 - 7 } & Historical indicators and targets & $70 \%$ & $30 \%$ & $100 \%$ \\
\hline
\end{tabular}


Table 4 (cont.). Disclosure of general performance indicators and relevance enhancing on-line reporting features

\begin{tabular}{|c|c|c|c|c|c|}
\hline No & Category & Disclosure item & $\begin{array}{l}\text { Percentage of } \\
\text { companies that } \\
\text { disclose }\end{array}$ & $\begin{array}{c}\text { Percentage of } \\
\text { companies that do } \\
\text { not disclose }\end{array}$ & Total \\
\hline \multirow{5}{*}{9} & \multirow{5}{*}{$\begin{array}{l}\text { Relevance } \\
\text { enhancing on-line } \\
\text { reporting features }\end{array}$} & $\begin{array}{l}\text { Use of some on-line features for enhancing relevance of } \\
\text { environmental reports }\end{array}$ & $85 \%$ & $15 \%$ & $100 \%$ \\
\hline & & $\begin{array}{l}\text { Use features that allow users to tailor their reports according } \\
\text { to their needs }\end{array}$ & $79 \%$ & $21 \%$ & $100 \%$ \\
\hline & & $\begin{array}{l}\text { Use externally recordable web features to enable readers to } \\
\text { edit and share their views about a company's report }\end{array}$ & $32 \%$ & $68 \%$ & $100 \%$ \\
\hline & & $\begin{array}{l}\text { Use web technologies such as the social media to engage } \\
\text { with the stakeholders }\end{array}$ & $32 \%$ & $68 \%$ & $100 \%$ \\
\hline & & $\begin{array}{l}\text { use on-line facilities such as hit counters to track the number } \\
\text { of stakeholders that accessed their on-line }\end{array}$ & $2 \%$ & $98 \%$ & $100 \%$ \\
\hline
\end{tabular}

Source: Global Reporting Initiative (2015), Kamala (2014).

Although the disclosure of general performance indicators by high percentage ( $91 \%$ of companies) is encouraging, the relatively lower percentage of companies disclosing both historical indicators and targets $(70 \%)$ suggests that a significant percentage of companies did not provide a direction towards which they were headed, a situation likely to hamper a decision-making by users who are generally interested in the future direction of a company. This could also suggest that the general indicators reported without targets were just reported for the sake of it without commitment to improving performance, the situation that results in general and mostly irrelevant information.

Given the emergence of the Internet as an effective medium for disseminating information, the fact that a high percentage ( $85 \%$ of companies) used the features of the medium to enhance the relevance of their reports is encouraging. Equally encouraging was the fact $75 \%$ of the companies' websites enabled users to tailor their reports to their needs. However the fact that only $32 \%$ of the companies' website enabled users to add and share their views, or even engage each other about the company's environmental performance suggest that companies were not keeping pace with the emerging on-line features that provide some of the most effective tools for dialogue and engagement with increasingly sceptical stakeholders. Even worse, the failure of almost all companies to use on-line facilities track the number of stakeholders that accessed their on-line environmental reports suggests they had no way determining the frequency of use of different segments of their reports. Thus, they are likely to have missed an opportunity to determine the types of environmental information that were popular with the audience, or even better, target the readers, the situation is likely to result in provision of an irrelevant environmental report.

\section{Summary and conclusions}

This paper sought, by way of a content analysis methodology, to assess the relevance of environmental reports produced by the T100 LSA companies. The results of this paper indicate that almost all of sampled companies disclosed how they identified their stakeholders, the relative importance of stakeholders, methods employed to engage stakeholders and the different methods to engage with different stakeholders. The disclosure of the above-mentioned items by an overwhelming majority of sampled companies in the current study is encouraging, as it is not only recommended by the GRI guidelines, but through such disclosure, companies demonstrate that they know who their stakeholders are and how to engage with them. It is the knowledge that enables companies to provide relevant information.

With regard to the stakeholder engagement process and outcome, the results of the current study show that that a high percentage of sampled companies disclosed their engagement process, outcomes and criteria for selecting content to be reported, however most of them did not disclose the use of a consistent metric to quantify the effectiveness of their stakeholder engagement process.

It is suggested that their engagement exercise is unfocused, prone to trial and error, the situation is unlikely to resolve the stakeholders' concerns. Concerning the disclosures on how selection of content that is reported on is done, the results of current study indicate that most of the companies disclosed the criteria used for selection of the content reported on, the rationale behind the choice of key impacts, explained how the issues are prioritized within reports, and consulted with stakeholders when selecting the content to report on. In addition, most of the companies disclosed that they referredto the GRI guidelines when selecting the content to report on, although only a minority referred to GRI sector specific indicators. The latter may suggest provision of general indicators that do not reflect the key performance areas of a company, an aspect likely to undermine the relevance of environmental reports. However, given that most 
companies disclosed their process for assessing materiality of issues as well as their materiality matrix, it is more likely than not the reports produced were relevant.

As far as the disclosure of how companies address stakeholders' concerns and encourage stakeholder participation is concerned, the results of current study revealed that most of sampled companies disclosed how key stakeholders' concerns are addressed, characterized and described stakeholders' interest and needs for environmental information, and disclosed efforts made to cater for specific needs of different stakeholders. In addition, most of companies disclosed their response to stakeholders concerns that were raised during the engagement process, however a significantly lesser percentage of companies disclosed the stakeholders' criticisms or their response to the criticisms, which suggests disregard for stakeholders' criticism that can undermine the relevance of reports to them. The results also reveal that an overwhelming majority of the sampled companies disclosed an avenue for stakeholders' feedback, responded publicly to the feedback and provided a direct contact for the personnel responsible for environmental reporting. However, only a minority invited users to be a part of the writing process. With the exception of the latter, the above findings are encouraging as they show a commendable effort by companies to address key stakeholders' concerns, by identifying, characterizing and describing their specific interests, needs and concerns, the situation likely to result in provision of relevant information.

The disclosure of initiatives by an overwhelming majority of companies to encourage stakeholders to participate in companies' activities, provide the avenue for stakeholders' feedback, respond publicly to the feedback, provide a direct contact for the personnel responsible for environmental reporting increased chances of provision of relevant information. However, the relatively low percentage of companies that invited the users to be a part of the writing process by enabling the users to edit report content, add notes or analyze information suggests reluctance by companies to meaningfully engage the stakeholders.
With respect to disclosure of general performance indicators and relevance enhancing on-line reporting features, the results indicated that most of the sampled companies disclosed the generally applicable environmental indicators, historical indicators and targets. Likewise, most of the sampled companies used some on-line features for enhancing the relevance of their environmental reports, as well as features that allow users to tailor their reports according to their needs. However, only a minority of the sampled companies used externally recordable web features to enable readers to edit and share their views about a company's report, used web technologies such as the social media to engage with the stakeholders or even used on-line facilities such as hit counters to track the number of stakeholders that accessed their on-line.

Taken together, the above results indicate that the environmental reports produced by listed South African companies are relevant. However, the results suggest some areas in which the relevance of the reports could be improved, key among which include the use of a consistent matric to quantify the effectiveness of the stakeholder engagement, reference to GRI sector specific indicators, inviting users to be a part of the writing process, enabling them to use on-line features to edit, analyze and share environmental information, as well as tracking the use of the information.

The findings of this article have implications for listed South African companies as they will be made aware of various approaches adopted by their counterparts to enhance the relevance of their environmental reports. This information should not only enhance their buy-in on the need to produce relevant environmental reports, but also should enable them to evaluate their own environmental reporting practice in order to decide whether to improve, change or continue with their current practice. Researchers may also employ the content analysis approach such as the one adopted in this study to evaluate the other qualitative characteristics that make a non-financial report more decisionuseful such as reliability, comparability, understandability and verifiability.

\section{References}

1. Alrazi, B., De Villiers, C. \& Van Staden, C. (2011). The comprehensiveness of environmental reporting by global electric utilities: The type of information and the reporting media. Paper submitted at the NZ Sustainability Accounting Research Symposium, Auckland, August.

2. Antonites, E. \& De Villiers, C.J. (2003). Trends in South African corporate environmental reporting: a research note, Meditari Accountancy Research, 11, pp. 1-10.

3. Bartlett, S. \& Chandler, R.A. (1997). The corporate report and the private shareholder: Lee and Tweedie twenty years on, British Accounting Review, 29(3), pp. 245-261.

4. Beattie, V. \& Pratt, K. (2002). Voluntary annual report disclosures: what users want, The Institute of Chartered Accountants of Scotland, Edinburgh.

5. Bromley, P. \& Powell, W.W. (2012). From smoke and mirrors to walking the talk: Decoupling in the contemporary world, Academy of Management Annals, 6(1), pp. 483-530. 
6. Business \& Society, Morris \& Chapman (2010). Survey of best practices, trends and benchmarks in sustainability reporting. Available at: http://www.businessandsociety.be/.../883c0525 [Accessed 28 December 2010].

7. Came, F. (2011). Do markets really respond to corporate sustainability efforts? Available at: http://www.greenbiz.com/news/2011/03/24/ [Accessed 15 January 2013].

8. Campbell, D. \& Slack, R. (2008). Narrative reporting: analysts'perceptions of its value and relevance. Available at: http://www2.accaglobal.com/pubs/economy/analysis/acca/.../tech_3.pdf[ Accessed 10 January 2012].

9. CERES \& ACCA 2010. Coalition for Environmentally Responsible Economies (CERES) \& Association of Chartered Certified Accountants (ACCA). (2010). Report of the judges: CERES-ACCA North American Awards for sustainability reporting 2010. Available at:http://www.ceres.org/resources/reports/2010-judges-report/at_download/file [Accessed 20 December 2010].

10. Danastas, L. \& Gadenne, D. (2006). Social and Environmental NGO's as users of Corporate Social. Disclosure, Journal of Environmental Policy and Management, 8(1), pp. 85-102.

11. Deegan, C. (2002). The legitimising effect of social and environmental disclosures: a theoretical foundation, Accounting, Auditing \& Accountability Journal, 15(3), pp. 282-311.

12. Deegan, C. \& Blomquist, C. (2006). Stakeholder influence on corporate reporting: an exploration of the interaction between the World Wide Fund for nature and the Australian minerals industry, Accounting, Organizations and Society, 31(45), pp. 343-372.

13. Deegan, C. \& Islam, M. (2009). NGO's use of the media to create changes in corporate activities and accountabilities: evidence from a developing country. Paper presented at the Accounting \& Finance Association Conference of Australia and New Zealand (AFAANZ), Adelaide. July.

14. Deegan, C. \& Rankin, M. (1997). The materiality of environmental information to users of annual reports, Accounting, Auditing and Accountability Journal, 10(4), pp. 562-583.

15. Deegan, C. \& Rankin, M. (1999). The environmental reporting expectations gap: Australian evidence, British Accounting Review, 31(3), pp. 313-346.

16. Delmas, M. \& Burbano, V.C. (2011). The Drivers of Greenwashing, California Management Review, 54(1), pp. 64-87.

17. De Villiers, C.J. (1998a). South African environmental reporting: what it is, what it should be. Available at: http://www.www3.bus.osaka-cu.ac.jp/apira98/archives/pdfs/18.pdf [Accessed 23 March 2010].

18. De Villiers, C.J. \& Lubbe, D.S. (2001). Industry differences in respect of corporate environmental reporting in South Africa: A research note, Meditari Accountancy Research, 9, pp. 81-91.

19. De Villiers, C.J. \& Van Staden, C.J. (2006). Can less environmental disclosure have a legitimising effect? Evidence from Africa, Accounting, Organizations and Society, 31, pp. 763-781.

20. De Villiers, C. \& Van Staden, C. (2008). Environmental accountability: a shareholder requirement? Paper presented at the Accounting \& Finance Association of Australia and New Zealand (AFAANZ), Adelaide. July.

21. De Villiers, C. \& Van Staden, C. (2009). Good, bad and crisis firms: how much and where they disclose environmental information. Paper presented at the Accounting \& Finance Association of Australia and New Zealand (AFAANZ), Adelaide. July.

22. De Villiers, C. \& Van Staden, C.J. (2010). Shareholders' requirements for corporate environmental disclosures: a cross country comparison, British Accounting Review, 429(4), pp. 227-240.

23. De Villiers, C. \& Van Staden, C. (2011). Where firms choose to disclose voluntary environmental information, Journal of Accounting and Public Policy, 30(6), pp. 504-521.

24. De Villiers, C.J. \& Vorster, Q. (1995). More corporate environmental reporting in South Africa? Meditari Accountancy Research, 3, pp. 44-66.

25. De Vries, I. \& De Villiers, C.J. (1997). Ethical investing by South African unit trust managers, Meditari Accountancy Research, pp. 3-43.

26. Epstein, M. \& Friedman, M. (1994). Social disclosure and the individual investor, Accounting, Auditing and Accountability Journal, 7(4), pp. 94-109.

27. European Commission. (2011b). The state of play in sustainability reporting in the European Union. Available at: http://www.ec.europa.eu/social/BlobServlet?docId=6728\&langId=en [Accessed 25 January 2012].

28. FASB. (2010). Conceptual framework: statement of financial accounting concepts No. 8. Available at: http://www.www.fasb.org/cs/BlobServer?blobcol...id...application\%2Fpdf [Accessed 15 January 2011].

29. Flammer, C. (2012). Corporate social responsibility and stock prices: The environmental awareness of shareholders. Available at: http://www.corporate-sustainability.org/conferences/fourth./Flammer.pdf [Accessed 16 September 2014].

30. Futtera Sustainability Communication (FSC), Sustainability \& KPMG. (2010). Reporting change: readers \& reporters survey 2010. Available at: http://www.futerra.co.uk/download s/Reporting_Change.pdf [Accessed 25 May 2011].

31. Fonseca, A. (2010). Barriers to strengthening the Global Reporting Initiative framework: exploring the perceptions of consultants, practitioners, and researchers. Available at: http://www.csinrcid.ca/downloads/csin_conf_alberto_ fonseca.pdf [Accessed 13 June 2011].

32. Global Reporting Initiative (GRI). (2013). G4 Guidelines - Reporting principles and standard disclosures. Available at: https://www.globalreporting.org/resourcelibrary/GRIG4-Part1-Reporting-Principles-and-Standard-Disclosures.pdf [Accessed 16 September 2014].

33. GRI. (2015). G4 Sustainability Reporting Guidelines. Available at: https://www.globalreporting.org/standards /g4/Pages/default.aspx [Accessed 16 February 2016]. 
34. Haque, S., Deegan, C. \& Inglis, R. (2013). Disclosure of climate change-related corporate governance practices. Paper presented at the Asia Pacific Interdisciplinary Research in Accounting Conference, Kobe, Japan. July.

35. IASB. (2010). Conceptual framework for financial reporting 2010. Available at: http://www.ifrs.org [Accessed 2011-09-01].

36. Institute of Directors in Southern Africa (IODSA). (2012). Practice notes: Reporting in terms of the JSE listing requirements. Available at: http://www.iodsa-gai.co.za/documents/IoDSA_GAI_Handout_2012.pdf [Accessed 20 May 2013].

37. Integrated Reporting Committee (IRC). (2011). Framework for integrated reporting and the integrated report discussion paper. Available at: http://www.sustainabilitysa.org [Accessed 22 August 2011].

38. Islam, M. \& Deegan, C. (2010). Media pressures and corporate disclosure of social responsibility performance: A case study of two global clothing and sports retail companies, Accounting and Business Research, 40(2), pp. 1-20.

39. Jira, C.F. \& Toffel, M.W. (2013). Engaging supply chains in climate change, Manufacturing and Service Operations Management, 15(4), pp. 559-577.

40. Johansson, J. (2007). Sell-side analysts' creation of value - key roles and relational capital, Journal of Human Resource Costing and Accounting, 11(1), pp. 30-52.

41. Jollands, S., Akroyd. C. \& Sawabe, N. (2012). Investigating the role of stand-alone sustainability reports. Available at: http://www.apira2013.org/proceedings/pdfs/K300.pdf [Accessed 23 October 2012].

42. Jose, A. \& Lee, S. (2006). Environmental reporting of global corporations: A content analysis based on website disclosures, Journal of Business Ethics, 72, pp. 307-321.

43. Kamal, A.R. (2012). The relationship between corporate governance and environmental disclosure: UK evidence. Unpublished Doctor of Philosophy thesis, Durham, Durham University.

44. Kamala, P.N. (2014). The decision-usefulness of corporate environmental reports in South Africa. Unpublished Doctor of Commerce thesis, Pretoria, University of South Africa.

45. Kim, E.H. \& Lyon, T.P. (2012). Strategic environmental disclosure: Evidence from the DOE's voluntary greenhouse gas registry, Journal of Environmental Economics and Management, 61(3), pp. 311-326.

46. KPMG. (2008b). International survey of corporate responsibility reporting. Available at: http://www. kpmg.com/RutUS_prod/Documents/8/Corporate Sustainability_Report_US_Final.pdf. [Accessed 12 July 2015].

47. KPMG. (2011). International survey of corporate responsibility reporting 2011. Available at: http://www. kpmg.com/global/en/issuesandinsights/articlespublications/corporate-responsibility/pages/2011-survey.aspx. [Accessed 12 July 2015].

48. Krippendorff, K. (1980). Content analysis: An introduction to its methodology. Newbury Park: Sage Publications.

49. Laud, R.L. \& Schepers, D.H. (2009). Beyond transparency: Information overload and a model for intelligibility, Business and Society Review, 114, pp. 365-391.

50. Macnamara, J. (2005). Media content analysis: Its uses, benefits and best practice methodology, Asia Pacific Relations Journal, 6(1), pp. 1-34.

51. Marquis, C. \& Toffel, M.W. (2014). Scrutiny, Norms, and Selective Disclosure: A Global Study of Greenwashing. Available at: http://www.hbs.edu/faculty/Pages/item.aspx?num=40289 [Accessed 18 February 2016].

52. Mitchell, C.G. \& Quinn, N.W. (2005). Environmental reporting disclosure in South Africa: A comparative study of the expectations of selected groups of preparers and users, Meditari Accounting Research, 13(2), pp. 17-33.

53. Moneva, J.M. \& Cuellar, B. (2009). The value relevance of financial and non-financial environmental reporting, Environmental and Resource Economics journal, 44(3), pp. 441-456.

54. Myburgh, J.E. (2001). The informativeness of voluntary disclosure in the annual reports of listed industrial companies in South Africa, Meditari Accountancy Research, 9, pp. 199-216.

55. Noked, (N. 2013). The Corporate Social Responsibility Report and Effective Stakeholder Engagement. Available at: https://corpgov.law.harvard.edu/2013/12/28/ [Accessed 18 February 2016].

56. O'Donovan, G. (2002). Environmental disclosures in the annual report: Extending the applicability and predictive power of legitimacy theory, Accounting, Auditing \& Accountability Journal, 15(3), pp. 344-371.

57. Pricewaterhouse Coopers (PwC). (2007). Guide to key performance indicators. Available at: http://www.pwc.com/ gx/en/corporate-reporting/assets/pdfs/uk_kpi_guide.pdf [Accessed 12 May 2015].

58. Pricewaterhouse Coopers (PwC) \& Craib Design and Communications (CDC). (2009). A comprehensive survey of corporate social responsibility report trends, benchmarks and best practices. Available at: http//www.pwc.com/ca/en/sustainability/.../csr-trends-3-en.pdf. [Accessed 20 January 2016].

59. Pricewaterhouse Coopers (PwC) \& Craib Design and Communications (CDC). (2010). CSR trends 2010: Our fourth comprehensive survey of corporate social responsibility report trends, benchmarks and best practices. Available at: http//www.pwc.com/ca/en/sustainability/.../csr-trends-2010-09.pdf. Accessed [18 January 2016].

60. Radley Yeldar \& Global Reporting Initiative (GRI). (2011). Trends in online sustainability reporting. Available at: http://www..globalreporting.org/.../TrendsInOnlineSustainabilityReporting2011.p [Accessed 30 June 2015].

61. Rowbottom, N. \& Lymer, A. (2007). User demands for management commentary: The operating and financial review. Paper presented at the European Accounting Association Conference, Lisbon, April.

62. Said, R.M., Sulaiman, M. Ahmad, N.N. \& Senik, R. (2013). Environmental information usefulness: bank officers perceptions in Malaysia. Paper presented at the 4th international conference on business and economic research, Bandung, Indonesia, March. 
63. Solomon, J.F. \& Solomon, A. (2006). Private social, ethical and environmental disclosure, Accounting, Auditing \& Accountability Journal, 19(4), pp. 564-591.

64. Stainbank, L. \& Peebles, C. (2006). The usefulness of corporate annual reports in South Africa: perceptions of preparers and users, Meditari Accountancy Research, 14(1), pp. 69-80.

65. Zadjali, N. (2011). Advantages and disadvantages of Content Analysis. Available at: https://nuhaalzadjali9oo00oo9. wordpress.com/2011/01/10. [Accessed 30 June 2015]. 